DOI

\title{
ЗАСТОСУВАННЯ ЕНТЕРОСОРБЕНТУ "КАРБОЛАЙН" ПРИ КОРЕКЦІЇ ЗМІН ВІЛЬНОРАДИКАЛЬНОГО ОКИСНЕННЯ У ХВОРИХ НА ХРОНІЧНЕ ОБСТРУКТИВНЕ ЗАХВОРЮВАННЯ ЛЕГЕНЬ
}

\author{
๑С. В. Лотоцька, К. І. Бардахівська
}

ДВНЗ «Тернопільський державний медичний університет імені І. Я. Горбачевського МОз України», Інститут експериментальної патології, онкології і радіобіології імені Р. Є. Кавецького НАН України, Київ

\begin{abstract}
РЕЗЮМЕ. Наведено результати дослідження показників вільнорадикального окиснення у хворих на ХОЗЛ до та після лікування. Захворювання супроводжується збільшенням концентрації малонового діальдегіду та зменшенням вмісту супероксиддисмутази в сироватці крові. Відзначено позитивний вплив вуглецевого ентеросорбенту «Карболайн» в комплексному лікуванні таких хворих, про що свідчать зменшення рівня малонового діальдегіду та збільшення активності супероксиддисмутази в сироватці крові.

КЛЮчОВІ СЛОВА: ХОЗЛ, карболайн, малоновий діальдегід, супероксиддисмутаза.
\end{abstract}

Вступ. Хронічне обструктивне захворювання легень (ХОЗЛ) - це екологічно детерміноване захворювання, патофізіологічною основою якого $\epsilon$ хронічний запальний процес в легенях, коли у відповідь на вплив пошкоджувальних чинників зовнішнього середовища порушується баланс між активністю про- і антиоксидантних систем організму. В результаті окисного стресу, який виникає при ХОЗЛ, в організмі накопичуються токсичні продукти перекисного окиснення ліпідів (ПОЛ), що є однією з причин розбалансування регуляції гомеостазу і призводить до серйозних метаболічних порушень, зміни імунного статусу, порушення функціонального стану різних систем [1]. Відомо, що у хворих на ХОЗЛ процеси ПОЛ проходять інтенсивно і залежать від прояву легеневої недостатності $[2,3]$. Активація процесів ПОЛ зумовлює пошкодження клітинних мембран та їх рецепторного апарату, зумовлюючи бронхоспазм і дисбаланс $\beta$-адренергічної системи, призводить до набряку слизової оболонки бронхів за рахунок виходу біологічно активних речовин із погіршенням мікроциркуляції тканин, знижує мукоциліарний транспорт, і як наслідок - призводить до виникнення гіперсекреції [4]. Тому своєчасне виявлення і корекція змін вільнорадикального окиснення (BPO) у багатьох випадках допомагають запобігти прогресуванню захворювання.

Значне місце в комплексі лікувальних заходів має ентеросорбція (ЕС), оскільки сприяє помітному зменшенню проявів ендогенної інтоксикації. Цей метод заснований на здатності ентеросорбентів зв'язувати і виводити з організму різні екзогенні речовини, мікроорганізми і їх токсини, ендогенні проміжні та кінцеві продукти обміну. Є ряд наукових статей, присвячених вивченню ефективності застосування ЕС при різних захворюваннях $[5,6]$. Зараз існує багато видів ентеросорбентів з різним механізмом впливу на ор- ганізм. Вивчення медико-біологічних механізмів їх дії дозволило прийти до висновку, що на особливу увагу заслуговує вуглецевий ентеросорбент IV покоління «Карболайн», що складається з вуглецевих волокон АУТ-М з питомою поверхнею пор близько 2000-2500 $\mathrm{M}^{2} / г$ [7].

Метою нашої роботи було вивчити вплив вуглецевого ентеросорбента IV покоління «Карболайн», при включені його в комплексну терапію, на лабораторні показники ВРО, а саме - вміст малонового діальдегіду (МДА) та активність супероксиддисмутази (СОД) у сироватці крові хворих на ХОЗЛ.

Матеріал і методи дослідження. Відповідно до поставленої мети дослідження було обстежено 103 хворих на ХОЗЛ у стадії загострення. Серед них було 68 чоловіків (66 \%) і 35 жінок (34 \%). Середній вік склав $(58,27 \pm 1,20)$ років. Для встановлення діагнозу використовували рекомендації Адаптованої клінічної настанови «Хронічне обструктивне захворювання легень» (2013), Уніфікованого клінічного протоколу первинної, вторинної (спеціалізованої), третинної (високоспеціалізованої) медичної допомоги та медичної реабілітації «Хронічне обструктивне захворювання легень» $(2013)[8,9]$.

Обстежувані були поділені на 4 групи. Першу (контрольну) склали 20 здорових людей, зіставних за віком і статтю, другу - 34 пацієнти (22 \%) з бронхообструкцією легкого ступеня тяжкості (GOLD 1), третю - 64 пацієнти (41\%) з бронхообструкцією середнього ступеня тяжкості (GOLD 2), четверту - 57 хворих (37 \%) з тяжкою бронхообструкцією (GOLD 3).

Пацієнтам проводили диференційоване лікування.

51 хворий на ХОЗЛ одержував лише базисну терапію (БТ) згідно з наказом МОЗ України № 555 (11 осі6 - другої групи, 19 - третьої, 21 - четвертої). 
Огляди літератури, оригінальні дослідження, погляд на проблему

52 особи (33,5 \%) крім БТ додатково отримували перорально по 1 чайній ложці протягом 10 днів 3 рази на день за 2 години до або через 2 години після приймання їжі та медикаментозних засобів вуглецевий ентеросорбент IV покоління «Карболайн» у вигляді дрібних гранул (виробництва Інституту експериментальної патології, онкології і радіобіології ім. Р. Є. Кавецького НАН України) (12 осіб - другої групи, 22 - третьої, 18 - четвертої).

Інтенсивність процесів ПОЛ визначали за вмістом МДА в сироватці крові за реакцією з тіобарбітуровою кислотою за методом В. Н. Орехович [10]. Для вивчення антиоксидантного захисту (АОЗ) досліджували активність одного із основних його ферментів - СОД за методом С. Чеварті і співавт. [11]. Визначення проводили спектрофотометричним методом.

Обробка результатів виконана у відділі системних статистичних досліджень ДВНЗ «Тернопільський державний медичний університет імені І. Я. Горбачевського МОЗ України» в програмному пакеті Statsoft STATISTICA. Оцінку достовірності відмінностей між групами проводили зі застосовуванням непараметричного методу за U-критерієм Уілкоксона (Уітні-Манна) [12].

Результати досліджень та їх обговорення. При проведенні лабораторних досліджень до лікування пацієнтів із ХОЗЛ було встановлено, що зі збільшенням важкості захворювання зростав рівень МДА, що свідчило про активізацію процесів ПОЛ. Одночасно відмічалося зменшення активності СОД, що підтверджує пригнічення АОЗ. Результати наших спостережень свідчать, що призначення ентеросорбентів на тлі БТ сприяє зменшенню змін процесів ВРО, про що свідчать зменшення кількості МДА та підвищення вмісту СОД у крові хворих (табл. 1).

Рівень МДА у хворих на ХОЗЛ зростав пропорційно до тяжкості захворювання. Так, у II групі до лікування показник збільшився на $26 \%$ і становив $(3,61 \pm 0,12)$ мкмоль/л $(p<0,01)$. Після проведеної базисної терапії рівень МДА зменшився на 8 \%, а після поєднання її ентеросорбентом карболайн на $19 \%$, в о обох випадках різниця з контрольно групою була відсутня (p>0,05).

У III групі до лікування рівень МДА збільшився на $108 \%$ і дорівнював $(5,94 \pm 0,23)$ мкмоль/л. Після проведеної базисної терапії він зменшився на $22 \%$, а при застосуванні карболайну - на 46 \%. При порівнянні отриманих показників після застосування БТ з контрольною групою відмічалося зменшення їх в бік нормалізації $(p<0,05)$. Після поєднання БТ з карболайном різниця з контрольною групою була відсутня ( $>0,05)$, що може свідчити про покращення стану хворих.
В пацієнтів IV групи до лікування рівень МДА зріс на $116 \%$, порівняно з контрольної групою, i становив $(6,18 \pm 0,20)$ мкмоль/л. При призначенні БТ показник зменшився на $19 \%$, а при поєднанні останньої з ентеросорбцією - на 36 \% і дорівнював $(3,94 \pm 0,26)$ мкмоль/л, проте в обох випадках ще не досягав рівня контрольної групи.

Щодо показника АОЗ, то в результаті проведення лабораторного дослідження крові хворих на ХОЗЛ ми встановили, що якщо до лікування вміст СОД в II групі становив $(55,24 \pm 1,57)$ ум.од./мл, то після застосування БТ він підвищився на $9 \%$ до $(60,22 \pm 2,16)$ ум.од./мл, а після ентеросорбції - на $16 \%$, до $(63,91 \pm 2,28)$ ум. од./мл, і в обох випадках не відрізнявся від контрольної групи (р>0,05). Аналогічні зміни з цього показника спостерігали і в інших групах. У III групі до лікування рівень СОД в порівнянні з контролем був меншим на $21 \%$ і дорівнював $(50,48 \pm 1,43)$ ум. од./мл. При призначенні БТ показник підвищився на $14 \%$, а при поєднанні останньої з ентеросорбцією - на 23 \%, що лише на 3 \% було менше контрольних величин. У пацієнтів IV групи до лікування рівень СОД зменшився на 37 \%, порівняно з контрольної групою, і становив $(40,28 \pm 1,17)$ ум. од./мл. Після проведення БТ показник зріс на $19 \%$, а при застосуванні карболайну - на 37 \% і дорівнював $(55,24 \pm 3,04)$ ум. од./мл. При порівнянні отриманих показників з контрольною групою відмічалося зменшення їх в бік нормалізації.

В результаті комплексної оцінки наведених результатів ми отримали підтвердження, що ХОЗЛ супроводжується активізацією процесів ВРО, коли створюються умови додаткового накопичення в організмі пацієнтів різноманітних ендотоксинів, та зниженням АОЗ. Проте проведення БТ в поєднанні з ентеросорбентами, зокрема вуглецевими, нормалізує показники ПОЛ та покращує стан пацієнтів, зв'язуючи токсичні речовини в просвіті кишечника, зупиняючи процеси їх резорбції та рециркуляції в організмі і тим самим ослаблюючи клінічні прояви ендотоксикозу. Це дозволяє значно зменшити ступінь тяжкості патологічного процесу і супутніх ускладнень в майбутньому.

Висновки. 1. ХОЗЛ супроводжується вираженими змінами в системі ПОЛ-АОЗ, про що свідчать збільшення кількості МДА та зменшення активності СОД в сироватці крові.

2. Відзначено позитивний вплив ентеросорбенту «Карболайн» на показники вільнорадикального окиснення, порівняно з пацієнтами, що отримували лише базисну терапію в комплексному лікуванні хворих на ХОЗЛ.

Перспективи подальших досліджень. В подальшому планується вивчити вплив ентеросорбента «Карболайн» на інші показники ендотоксикозу у хворих на ХОЗЛ різного ступеня важкості та віку. 


\section{ЛІТЕРАТУРА}

1. Габор М. Л. Стан антиоксидантного захисту, процеси перекисного окислення ліпідів та цитокіновий статус у хворих на хронічне обструктивне захворювання легень // М. Л. Габор, О. І. Лемко // Український медичний альманах. - 2010. - Т. 13, № 3. - С. 40-42.

2. Изменения перекисного окисления липидов при бронхиальной обструкции / Е. А. Вострикова, О. В. Кузнецова, И. Т. Ветлугаева [и др.] // Пульмонология. 2006. - № 1. - C. 64-67.

3. Yigla M. Oxidative stress indices in COPD - Bronchoalveolar lavage and salivary analysis / M. Yigla, Y. Berkovich, R. Nagler // Arch. Oral. Biol. - 2007. - Vol. 52, № 1. P. 36-43.

4. Амеліна Т. М. Патогенетичне обґрунтування використання карведилолу у хворих на ішемічну хворобу серця з супутнім хронічним обструктивним захворюванням легень / Т. М. Амеліна // Буковинський медичний вісник. - 2008. - Т. 12, № 4. - С. 23-26.

5. Интенсивная терапия: национальное руководство: в 2 т. / под. ред. Б. Р. Гельфанда, А. И. Салтанова. М. : ГЭОТАР-Медиа, 2011. - Т. ІІ. - 784 с.

6. Сорока Ю. В. Сорбційна корекція змін імунологічної реактивності щурів за умов експериментального канцерогенезу та застосування хіміотерапевтичних чинників / Ю. В. Сорока // Світ медицини та біології. № 4. -2013 . - С. 82-86.
7. Аналіз адсорбції білокзв'язаних метаболітів i токсинів, характерних для печінкової недостатності, ентеросорбентами різного походження / Л. О. Юшко, В. В. Сарнацька, Л. О. Сахно [та ін.] // Доповіді Національної академії наук України. - 2009. - № 9. С. $177-181$.

8. Хронічне обструктивне захворювання легень. Адаптована клінічна настанова, заснована на доказах : Наказ МОЗ України від 27.06.2013 р. № 555.

9. Наказ МОЗ України від 27.06.2013 № 555 «Уніфікований клінічний протокол первинної, вторинної (спеціалізованої), третинної (високоспеціалізованної) медичної допомоги та медичної реабілітації», «Хронічне обструктивне захворювання легень». - [Чинний від 2013-06-27]. - К. : Міністерство Охорони Здоров я України. $-2013 .-92$ c.

10. Орехович В. Н. Современные методы в биохимии / В. Н. Орехович. - М. : Медицина, 1977. -268 с.

11. Чеварти С. Роль супероксиддисмутазы в окислительных процессах клетки и метод определения ее в биологических материалах / С. Чеварти, И. Чаба, И. Секей // Лабораторное дело. - 1985. - № 11.C. 678-681.

12. Реброва О.Ю. Статистический анализ медицинских данных. Применение пакета программ Statistica / О. Ю. Реброва. - М. : МедиаСфера, 2006. - 312 с.

\section{THE USE OF CHELATOR «KARBOLAYN» FOR CORRECTION OF THE CHANGES OF FREE RADICAL OXIDATION IN PATIENTS WITH CHRONIC OBSTRUCTIVE PULMONARY DISEASE}

\section{@S. V. Lototska, K. I. Bardakhivska}

SHEI «Ternopil State Medical University by I. Ya. Horbachevsky of MPH of Ukraine», Institute of Experimental Patholology, Oncology and Radiobiology by R. Ye. Kavetskyi of NAS of Ukraine, Kyiv

SUMMARY. There are presented the results of the study of indicators of free radical oxidation in COPD patients before and after treatment. The disease is accompanied by increasing concentration of malondialdehyde and the reduction content of superoxide dismutase in serum. The positive impact of carbon enterosorbent "Karbolayn" was noted in the treatment of these patients - as evidence was the reduction of malondialdehyde and increase superoxide dismutase activity in serum.

KEY WORDS: COPD, karbolayn, malondialdehyde, superoxide dismutase. 